\title{
Occurrence of F42 colonization factor in Escherichia coli strains isolated from piglets with diarrhea ${ }^{1}$
}

\author{
Mário Paulo A. Penatti ${ }^{2}$, Alex S. Silva ${ }^{3}$, Geórgio F. Valadares ${ }^{3}$ \\ and Domingos S. Leite ${ }^{3}$
}

\begin{abstract}
Penatti M.P.A., Silva A.S., Valadares G.F. \& Leite D.S. 2005. Occurrence of F42 colonization factor in Escherichia coli strains isolated from piglets with diarrhea. Pesquisa Veterinária Brasileira 25(1):31-33. Depto Microbiologia e Imunologia, Instituto de Biologia, Unicamp, Campinas, SP 13081-970, Brazil. E-mail: domingos@unicamp.br

The objective of this study was to determine the presence of the colonization factor F42 in 168 strains of Escherichia coli isolated from diarrheic stools of newborn piglets. The presence of F42 in $12(7.1 \%)$ strains was detected with the agglutination test. Through the Polymerase Chain Reaction (PCR) of F42 positive strains, gene encoding enterotoxins (ST-I, ST-II, LT-I and LT-II) were detected. The finding of ST-I/ST-II genes in 50\% of the strains, ST-I (16\%) and ST-II (25\%) indicates a strong association of FC F42 with heat-stable enterotoxins (91\%). In contrast, the thermolabile enterotoxin (LT-I and LT-II) genes were not detected. Serogroups of F42 positive strains were determined, serogroup 08 being the most prevalent $(41,7 \%)$. Other serogroups, as there are $09,011,018$, 032, O35, 098 and 0101, were also identified. Thus, FC F42 was confirmed as an additional factor of virulence in the pathogenesis of porcine colibacillosis.
\end{abstract}

INDEX TERMS: Escherichia coli, F42, piglets, fimbriae, diarrhea, PCR.

RESUMO.- [Prevelância do fator de colonização F42 em amostras de Escherichia coli isoladas de leitões com diarréia.] Este estudo determinou a presença do fator de colonização (FC) F42 em 168 amostras de Escherichia coli isoladas de suínos neonatos com diarréia. Ensaios de soroaglutinação determinaram a presença de F42 em $12(7,1 \%)$ das amostras bacterianas. As amostras de E. coli $\mathrm{F} 42$ positivas foram estudadas através de PCR quanto à presença de genes das enterotoxinas (ST-I, ST-II, LT-I e LT-II). 50\% das amostras apresentaram genes para ST-I/STII, $16 \%$ apresentaram genes para ST-I e 25\% genes para ST-II. Não foram observados resultados positivos para as enterotoxinas termo-lábeis (LT-I e LT-II), indicando forte associação do FC F42 com as enterotoxinas termoestáveis $(91 \%)$. O sorogrupo das amostras F42 positivas foi determinado, sendo o sorogrupo 08 prevalente $(41,7 \%)$ e uma amostra dos sorogrupos 09, 011, 018, 032, 035, 098, e 0101. Assim, o FC F42 foi confirmado como

\footnotetext{
${ }^{1}$ Received on February 23, 2003.

Accepted for publication on September 27, 2004.

2 Universidade Federal de Uberlândia, ESTES, Uberlândia, MG 38400-

${ }^{3}$ Depto Microbiologia e Imunologia, Instituto de Biologia, Unicamp, Campinas, SP 13081-970, Brasil. *Author for correspondence. E-mail: domingos@unicamp.br
} 902, Brazil. um fator de virulência adicional na patogênese da diarréia neonatal suína.

TERMOS DE INDEXAÇÃO: Escherichia coli, F42, leitões, fímbria, diarréia, PCR.

\section{INTRODUCTION}

Escherichia coli, which causes enterotoxic colibacillosis in suckling pigs, are refered to enterotoxigenic $E$. coli (ETEC) strains. They adhere to the microvilli of small intestinal epithelial cells and produce enterotoxins that act locally on the enterocytes (Nagy \& Feket 1999). For pigs ETEC, the most common adhesins (also called colonization factors) are K88, K99 and 987P (Alexander 1994). In 1986, a new E. coli ETEC colonization factor (F42) isolated from feces of newborn piglet was described by Yano et al. (1986). Such strains showed mannose resistant haemagglutination (MRH) of chicken, guinea pig, sheep, horse and human erythrocytes. They also showed diffuse adherence into HeLa cells (human cervix carcinoma) and piglet enterocytes (Yano et al. 1986). Electron microscopy showed the presence of structures such as fimbriae when strains were cultured at $37^{\circ} \mathrm{C}$ but not at $18^{\circ} \mathrm{C}$. The antiserum anti-F42 inhibited not only hemagglutination but also adherence to both HeLa cells and piglet intestinal epithelium, showing that the fimbriae were responsible for the adhesion. 
Later, Silveira et al. (1987) reported that F42, is associated with a non conjugative plasmid of 21.1 MDa coding for the heat-stable toxin (ST-I).

The purified F42 had a mass of $31 \mathrm{KDa}$ and an isoeletric point of $\mathrm{pH}$ 3.2. Polyclonal antiserum anti-F42 obtained from the purified fimbriae, did not cross react with other haemagglutinating adhesins of pig origin (Leite et al. 1988). Castro et al. (1990) demonstrated that strains of F42 E. coli caused diarrhea in piglet when inoculated orally and could be detected by direct immunofluorescence in the small intestine of these animals after 42 hours.

Leite et al. (1997) showed that the hemagglutination caused by the $\mathrm{F} 42$ fimbriae was sensitive to the $\mathrm{N}$-acetyl-galactosamine. In addition, potential receptors of F42 were shown through enzymatic treatment, to be a glycoprotein. They also verified, through Western Blotting that the reaction of F42 with membrane components varied with the source of the erythrocytes by different molecular structures.

In the present study, we report the detection of F42 among E. coli strains of piglets, their occurrence with the enterotoxins (ST-I and ST-II) genes and with serogroups.

\section{MATERIALS AND METHODS}

E. coli strains and growth conditions. A collection of $168 \mathrm{E}$. coli isolated from diarrheic feces of newborn piglets were studied. Standard strains used were: E. coli $567 / 7,08: \mathrm{H}^{-}, \mathrm{F}_{2} 2^{+} \mathrm{ST}^{-\mathrm{I}^{+}}$; O101, $\mathrm{F}^{+}, \mathrm{ST}^{+}{ }^{+} ; 40 \mathrm{~T}-\mathrm{LT}^{-} \mathrm{I}^{+}$; P17 - ST-II ${ }^{+}$; PCLT-II - LT-II ${ }^{+}$; DH 5a e K12. For F42 detection the cultures were grown on Minimal Salt Medium (MM) (Davis \& Mingioli 1950) containing $1.5 \%$ of Agar and $0.5 \%$ of glucose at $37^{\circ} \mathrm{C}$, TSA (Trypticase Soy Agar, Difco) for serogroup test, and Luria Bertani broth (LB) for DNA amplification.

F42 detection. The $E$. coli strains were cultured overnight at $37^{\circ} \mathrm{C}$ on MM agar. The detection of F42 production was performed by slide agglutination test using specific anti-F42 rabbit antiserum (Leite et al. 1988).

Polymerase Chain Reaction. The strains were first screened in order to detect the presence of F42. Afterwards the positive strains in this reaction were subjected to PCR tests. Amplifications were made using $50 \mathrm{mg}$ of purified DNA as template. PCR reactions were performed following the methodology described by Blanco et al. (1997) using specific primers for the genes that codify the toxins: LT-I, Blanco et al. (1997); LT-II, Pickett et al. (1986); ST-I and ST-II, Ojeniyi et al. (1994).

Determination of the serogroups. The serogrouping was determined using a microplate technique described by Guinée et al. (1972) and modified by Blanco et al. (1992).

\section{RESULTS}

The slide agglutination test using rabbit polyclonal anti-serum anti-F42 identified $12(7.1 \%)$ strains positive out of 168 isolates.

Among the 12 strains, 6 (50\%) which had the genes for ST-I and ST-II, 3 (25\%) were positive for ST-II, $2(16 \%)$ for ST-I, and not any strain was positive for LT-I or LT-II in PCR. Only one was not toxigenic.

The serogroups from $12 \mathrm{~F} 42+$ strains were determined: 5 reacted with anti-serum $08(41.7 \%)$; antisera to $09,011,018$, 032, 035, 098 and 0101 reacted with a single isolate.

The combination of all results is shown in Table 1.
Table 1. Enterotoxic genotypes and serogroups results of F42 Escherichia coli strains isolated of feces from diarrheic piglets

\begin{tabular}{ccc}
\hline ST-I & ST-II & $\begin{array}{c}\text { Serogroup(s) } \\
\left(\mathrm{n}^{\mathrm{O}} \text { of strains }\right)\end{array}$ \\
+ & + & O8 (3); O9(1); O11 (1); O32 (1) \\
+ & - & $098(1) ; 0101(1)$ \\
- & + & $08(1) ; 018(1) ; 035(1)$ \\
- & - & $08(1)$
\end{tabular}

\section{DISCUSSION}

In this study, the presence of the F42 colonization factor in $E$. coli strains from piglets with diarrhea, was identified. Through the slide agglutination test, the presence of F42 in 12 strains (7.1\%) of the 168 strains was shown. These observations are in agreement with the previous report of Zerbini (1993) that showed the presence of $\mathrm{F} 42$ in $7.4 \%$ of the strains studied. The similarity of the FCs already described, the prevalence of which were observed in different studies, showed heterogeneous results in different countries. Our results suggest that FC F42 must be considered as a factor of virulence in porcine colibacillosis.

In our experiments, no amplification of primers for the thermo-labile enterotoxins (I or II) could be observed. These results are not surprising, as others reported that enterotoxin LT has not been detected, or that it has been detected in a small number of strains isolated from pigs (Woodward \& Wray 1990, Flores-Abuxapqui et al. 1997, Osek 1998, Parma et al. 2000). Thus, the results let us conclude that probably FC F42 is not linked the the occurrence of this enterotoxin. On the other hand, the presence of the genes encoding ST-II and ST-I enterotoxins were found by us. The correlation between ST-I and ST-II was $50 \%$ of the total of the strains studied. In summary, all the results obtained, show the prevalence of genotypes profiles ST-I+ STII+ observed in 6 strains from serogroups 08 (3), 09 (1), 011 (1) and 032 (1). The genotype profile ST-I ST-II+ was found in 3 strains of the serogroups 08,018 and 035 , and the genotype profile ST-I+ ST-II' was found in 2 strains of serogroups 098 and 0101.

The correlation of ST-II enterotoxin with other colonization factors varies greatly and ranges from $0 \%$ to $78 \%$; according to Söderlind et al. (1988) in 21\%, Nagy et al. (1990) in 38\%, Blanco et al. (1997) in 78\%, Osek (1998) in 30\%, Know et al. (1999) and according to Osek (1999) in 4.5\%, but in non of the strains by Parma et al. (2000).

The serogroup 08 (41.7\%) was predominant in our study, confirming the initial comment made by Yano et al. (1986). On the other hand, serogroups 09, 011, 018, 032, 035, 098 and 0101 showed association with F42, what has not been described so far.

The combination of several factors was observed also for the colonization/enterotoxins in ETEC with neonatal diarrhea (Guineé \& Jansen 1979, Gaastra \& De Graaf 1982, Castro et al. 1984, Mainil et al. 1998). We demonstrated here the importance of the colonization factor F42 for the development of diarrhea in infections for ETEC, and the necessity of including this FC in the vaccine, in order to provide a major protection for the animals. 
We think that more screening is needed, which includes variables such as age, race and breeding practices in distinct geographic regions to further clarify the distribution and association of this colonization factor.

Acknowlegements.- This study was supported by grants (97/7729-1 and 98/11957-2) from the FAPESP, CAPES and CNPq.

\section{REFERENCES}

Alexander T.J.L. 1994. Neonatal diarrhoea in pigs, p.151-169. In: Gyles, C.L. (ed.) Escherichia coli in Domestic Animals and Humans. Cab International, Wallingford, UK.

Blanco J., Blanco M., Alonso M.P., Blanco J.E., Garabal J.I. \& González E.A. 1992. Serogroups of Escherichia coli strains producing cytotoxic necrotizing factors CNF1 and CNF2. FEMS Microbiol. Lett. 9:155-160.

Blanco M., Blanco J.E., González E.A., Mora A., Jansen W.H., Gomes T.A.T., Zerbine L.F., Yano T., Castro A.F.P. \& Blanco J. 1997. Genes coding for Enterotoxins and Verotoxins in porcine Escherichia coli strains belonging to different O.K.H Serotypes, relationship with toxic phenotypes. J. Clin. Microbiol. 35:2958-2963.

Castro A.F.P., Serafim M.B., Brito J.R.F., Barcellos D.S.E.N. \& Colli I.A.G. 1984. Virulence factors present in cultures of Escherichia coli isolated from pigs in the region of Concórdia, Santa Catarina, Brazil. Pesq. Vet. Bras. 4:109-114.

Castro A.F.P., Piffer I.A., Serafim M.B., Leite D.S. \& Colli I.A. 1990. Reprodução experimental da colibacilose em leitões. Pesq. Vet. Bras. 10:11-18.

Davis B.D. \& Mingioli E.S. 1950. Mutants of Escherichia coli requiring methionine or vitamin B. J. Bacteriol. 60:17-28.

Flores-Abuxapqui J.J., Suarez-Hoil G.J., Puc-Franco M.D., Heredia-Navarrete M.R., Vivas-Rosel M.L. \& Oberhelman R.A. 1997. Frequency of adhesive factors and enterotoxins in strains of Escherichia coli isolated from piglets with diarrhea. Vet. Latinoam. Microbiol. 39:145-151.

Gaastra W. \& De Graaf F. K. 1982. Host-specific fimbrial adhesins of noninvasive Escherichia coli strains. Microbiol. Rev. 46:129-161.

Guinée P.A.M. \& Jansen W.H. 1979. Detection of enterotoxigenicity and attachment factors in Escherichia coli strains of human, porcine and bovine origin: a comparative study. Zbl. Bakt. I. Hyg. Abt. Orig. $\mathrm{A}(243): 245-257$.

Guinée P. A. M., Agterber C. M. \& Jansen W. H. 1972. Escherichia coli O typing by means of a mechanized microtechnique. Appl. Microbiol. 24:127-131.

Kwon D., Kim O. \& Chae C. 1999. Prevalence of genotypes for fimbriae and enterotoxins and of $\mathrm{O}$ serogroups in Escherichia coli isolated from diarrheic piglets in Korea. J. Vet. Diagn. Invest. 11:146-151.

Leite D.S., Yano T. \& Castro A.F.P. 1988. Production, purification and partial characterization of a new adhesine factor (F42) produced by enterotoxigenic Escherichia coli isolated from pigs. Ann. Inst. Pasteur / Microbiol. 139:295-306.

Leite D.S., Yano T. \& Castro A.F.P. 1997. Receptors on chicken erythrocytes for F42 fimbriae of Escherichia coli isolated from pigs. Zbl. Bakt. 286:383388.

Mainil J.G., Daube G., Jacquemin E. \& Pohl P. 1998. Virulence plasmids of enterotoxigenic Escherichia coli isolates from piglets. Vet. Microbiol. 62:291-301.

Nagy B. \& Feket P.Z. 1999. Enterotoxigenic Escherichia coli (ETEC) in farm animals. Vet. Res. 30:259-284.

Nagy B., Casey T. A. \& Moon H. W. 1990. Phenotype and genotype of Escherichia coli isolated from pigs with postweaning diarrhea in Hungary. J. Clin. Microbiol. 28:651-653.

Ojeniyi B., Ahrens P. \& Meyling A. 1994. Detection of fimbrial and toxin genes in Escherichia coli and their prevalence in piglets with diarrhoea. The application of colony hybridization assay, polymerase chain reaction and phenotypic assays. J. Vet. Med. 41:49-59.

Osek J. 1998. Application of polymerase chain reaction for determination of toxins in Escherichia coli strains isolated from pigs with diarrhea. Acta Microbiol. Pol. 47:409-413.

Osek J. 1999. Prevalence of virulence factors of Escherichia coli strains isolated from diarrheic and healthy piglets after weaning. Vet. Microbiol. 68, 209-217.

Parma A.E., Sanz M.E., Viñas M.R., Cicuta M.E., Blanco J.E., Boehring S.I., Vena M.M., Roibon W.R., Benitez M.C., Blanco J. \& Blanco M. 2000. Toxigenic Escherichia coli isolated from pigs in Argentina. Vet. Microbiol. 72:269-276.

Pickett C.L., Twiddy E.M., Belisle B.W. \& Holmes R.K. 1986. Cloning of genes that encode a new heat-labile enterotoxin of Escherichia coli. J. Bacteriol. 165:348-352.

Silveira W.D., Yano T., Azevedo J.L. \& Castro A.F.P. 1987. Plasmid-mediated production of a new colonization factor (F42) in enterotoxigenic Escherichia coli. Rev. Genet. 4:635-646.

Söderlind O., Thafvelin B. \& Möllby R. 1988. Virulence factors in Escherichia coli strains isolated from Swedish piglets with diarrhea. J. Clin. Microbiol. 26:879-884.

Woodward M. J. \& Wray C. 1990. Nine DNA probes for detection of toxin and adhesin genes in Escherichia coli isolated from diarrhoeal disease in animals. Vet. Microbiol. 25:55-65.

Yano T., Leite D.S., Camargo I.J.B. \& Castro A.F.P. 1986. A probable new adhesive factor ( $\mathrm{F} 42)$ produced by enterotoxigenic Escherichia coli isolated from pigs. Microbiol. Immunol. 30:1495-1508.

Zerbini L.F.C. 1993. Fatores de Virulência e Sorotipos de Escherichia coli isolada de suínos durante as primeiras semanas de vida. Master Thesis, Universidade Federal de São Paulo, São Paulo, Brazil 